\title{
THE VOICE OF GOVERNMENT AS AN ABRIDGEMENT OF FIRST AMENDMENT RIGHTS OF SPEAKERS: RETHINKING MEESE V. KEENE
}

Common perceptions about the freedom of expression focus on the desirability of a wide spectrum of individual expression. ${ }^{1}$ The traditional vision sees an ideological marketplace, where a panoply of views are freely expressed and openly judged by the public. ${ }^{2}$ Such a vision advocates that a properly functioning ideological marketplace is essential to the proper working of democratic self-governance. ${ }^{3}$ By proscribing that "Congress shall make no law ... abridging the freedom of speech ...." the first amendment makes an unequivocal statement that accords with the traditional view of freedom of expression, and significantly restricts the government's power to act directly against individual expression. ${ }^{4}$ But how are the values of individual expression affected when government itself speaks? Since the first amendment does not specifically address the government's rights as speaker, the application of the first amendment to government speech is not readily apparent. As interpreted by the courts, the first amendment provides conflicting signals: while more speech is generally considered good, it also suggests that the government should not intrude in the ideological marketplace.

While the courts over the past several decades have established a first amendment framework for analyzing individual expression, government speech has not received similar attention. Thus, the Supreme Court's recent decision in Meese v. Keene 5 is important since it indicates

1. See Whitney v. California, 274 U.S. 357, 375-77 (1927) (Brandeis, J., concurring) ("freedom to think as you will and to speak as you think are means indispensable to the discovery and spread of political truth").

2. See Abrams v. United States, 250 U.S. 616, 630 (1919) (Holmes, J., dissenting) ("[T]he best test of truth is the power of thought to get itself accepted in the competition of the market ...."); see also First Nat'l Bank v. Bellotti, 435 U.S. 765, 791 (1978) ("Moreover, the people in our democracy are entrusted with responsibility for judging and evaluating the merits of conflicting arguments.").

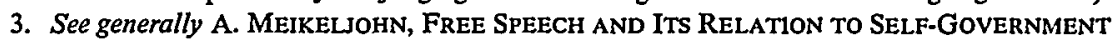
(1948).

4. "Congress shall make no law ... abridging the freedom of speech, or the press." U.S. CONST. amend. I (emphasis added).

5. 481 U.S. 465 (1987). 
that the Court may not regard government speech as fitting into the established framework. In Keene, the Court assessed the constitutionality of the United States Department of Justice's conduct in labeling three Canadian documentary films as "political propaganda." Having identified the films as "political propaganda," the Justice Department required that the films bear a label identifying their origin. Persons who wished to publicly show the films claimed that the Justice Department's labeling practices branded them as propagandists and discouraged them from exercising their first amendment rights. Although the facts of the case arguably presented an example of how government communication could be both protected speech and an abridgment of individual expression, the Court dodged the issue of government speech, and held that the designation of the films as "political propaganda" did not violate the exhibitors' first amendment rights. ${ }^{6}$ The Court's failure to identify the issues as government speech ${ }^{7}$ illustrates its reluctance to accept the notion that, in some circumstances, more speech (in this case, government speech) may in fact restrict speech. Such a paradox regarding government speechwhere more is less-is likely to intensify as the governinent's role as a communicator expands. ${ }^{8}$

Building on the groundbreaking work of several commentators, ${ }^{9}$ this Note proposes a workable framework for analyzing government

6. Id. at $484-85$.

7. The term "government speech" refers simply to government communication, or lack thereof. Government speech issues may be present in cases concerning government secrecy, school curriculum selection, and expenditures on campaign referenda.

8. See Z. Chafee, Government and Mass Communications: A Report from the COMMISSION ON FREEDOM OF THE PRESS 723 (1947).

9. While detailed discussions of the problems of government speech are sparse, several writers have begun the task of addressing the issue. The most thorough analysis is found in M. YUDOF, When Government Speaks: Politics, LaW, and Government Expression in AMERICA (1983). Other detailed discussions appear in Kamenshine, The First Amendment's Implied Political Establishment Clause, 67 CALIF. L. REv. 1104 (1979); Shiffrin, Government Speech, 27 UCLA L. Rev. 565 (1980); The Supreme Court, 1986 Term-Leading Cases, 101 Harv. L. Rev. 119, 209-19 (1987) (discussing Keene); Note, Unconstitutional Government Speech, 15 SAN DIEGo L. REV. 815 (1978) [hereinafter Note, Government Speech].

More focused works present helpful discussion of related issues. See Finman \& Macaulay, Freedom to Dissent: The Vietnam Protests and the Words of Public Officials, 1966 WIs. L. REv. 632; Van Alstyne, The First Amendment and the Suppression of Warmongering Propaganda in the United States: Comments and Footnotes, 31 LAW \& CONTEMP. Probs. 530 (1966); Ziegler, Government Speech and the Constitution: The Limits of Official Partisanship, 21 B.C.L. REv. 578 (1980); Note, The Constitutionality of Municipal Advocacy in Statewide Referendum Campaigns, 93 HARV. L. REv. 535 (1980).

More theoretical discussions of these issues are found in Z. CHAFEE, supra note 8, at 723-82 (examination of past and prospective governmental information agencies); T. EMERSON, THE SYSTEM OF FREEDOM OF EXPRESSION $697-716$ (1970) (government participation in expression and dissemination of views); J. TUSSMAN, GOVERNMENT AND THE MIND (1977) (arguing that government does have a role in shaping the intellect and spirit of its citizens). 
speech in terms of the first amendment. This Note relies on Keene as an illustration of how the government speech problem can arise and how the proposed framework can be apphed. Section I presents the statutory authority relied on by the Justice Department and describes the subsequent legal challenges. ${ }^{10}$ It then reviews the Court's opinion in Keene. ${ }^{11}$ Section II offers a constitutional framework for reviewing government speech, by analyzing the effect of government speech on society. ${ }^{12} \mathrm{Sec}-$ tion III takes another look at Keene, applying the framework developed in section II to conclude that a balance of the various interests and the effect of the communication will yield better reasoning and perhaps different results. ${ }^{13}$

\section{Three Canadian Films, the Department of Justice, and THE FoREIGN AGENTS REgistration ACT}

The Canadian films at issue in Keene were labeled as propaganda by the Justice Department under the authority of the Foreign Agents Registration Act (FARA). ${ }^{14}$ The Act, described below, enables the governinent to label foreign materials distributed here in an effort to mute the effect of the propaganda. Challenges to the Justice Department's labeling of the three films came swiftly in two cases, Block v. Meese, ${ }^{15}$ decided by the United States Court of Appeals for the District of Columbia Circuit, and Meese v. Keene. ${ }^{16}$ These two cases mark the first judicial review of the labeling provision of the FARA and provide a touchstone for further analysis of the role government speech can, and should, play in the marketplace of ideas.

\section{A. The FARA Provisions and Legislative History}

Congress enacted the Foreign Agents Registration Act (FARA) in

10. See infra notes $17-46$ and accompanying text.

Other commentators thoroughly covered this ground prior to the Supreme Court hearing the case. See Note, Neutral Propaganda: Three Films "Made in Canada" and the Foreign Agents Registration Act, 7 CoMm/ENT L.J. 435 (1985) [hereinafter Note, Neutral Propaganda]; Note, The "Political Propaganda" Label Under FARA: Abridgement of Free Speech or Legitimate Regulation?, 41 U. Miami L. Rev. 591 (1987) [hereinafter Note, "Political Propaganda" Label].

For an earlier discussion of the legislative background, see Note, Governmental Exclusion of Foreign Political Propaganda, 68 HARv. L. REv. 1393 (1955) [hereinafter Note, Foreign Political Propaganda].

11. See infra notes $47-74$ and accompanying text.

12. See infra notes $75-157$ and accompanying text.

13. See infra notes $158-74$ and accompanying text.

14. 22 U.S.C. $\$ \S 611-21$ (1982) [hereinafter FARA].

15. 793 F.2d 1303 (D.C. Cir.), cert. denied, 478 U.S. 1021 (1986).

16. 481 U.S. 465 (1987). 
193817 in response to a flood of publications entering the United States from foreign governments. ${ }^{18}$ Originally designed as a "sunshine statute," FARA exposed the efforts of foreign principals attempting to influence the political views of the American public. ${ }^{19}$ In its earhest form, FARA required only registration and disclosure, with sanctions imposed for failure to comply. ${ }^{20}$ FARA's purpose shifted over time, however, from that of exposing subversive propagandizing to spotlighting political lobbying and public relations directed at U.S. policymaking. ${ }^{21}$ As a result, amendments to the Act have expanded the burden on foreign principals by adding labeling and filing requirements for materials distributed in the U.S. ${ }^{22}$

17. Act of June 8,1938 , ch. 327,52 Stat. 631 (codified as amended at 22 U.S.C. $\$ \S 611-21$ (1982)).

18. The publicity focused on various Nazi and Communist campaigns. Note, Neutral Propaganda, supra note 10, at 435; see also Viereck v. United States, 318 U.S. 236, 244 (1943) (1938 Act enacted to register Nazi propaganda).

19. Act of April 29, 1942, ch. 263, 56 Stat. 248.

It is hereby declared to be the policy and purpose of this Act to protect the national defense, internal security, and foreign relations of the United States by requiring public disclosure by persons engaging in propaganda activities and other activities for or on behalf of foreign governments, foreign political parties and other foreign principals so that the Government and the people of the United States may be informed of the identity of such persons and may appraise their statements and actions in the light of their associations and activities.

Id. at 248-49.

Congress feared that such dissemination by foreign agents "might be thought by the public to be indigenously American, but which in actuality were subsidized and supported from abroad ...." Note, Foreign Political Propaganda, supra note 10, at 1396.

20. Act of June 8, 1938, ch. 327, $\S \S 2,5,52$ Stat. $631,632-33$ (codified as amended at 22 U.S.C. $\S \S 614,618$ (1982)) (registration and criminal sanction sections). Section 612(a) of the FARA forbids anyone to act as an agent of a foreign principal unless an accurate registration statement and periodic supplements, see 22 U.S.C. $\$ 612(b)$, are filed with the United States Attorney General. The registration statement must include a description of the business and activities of the agent, including "[a] detailed statement of every activity which the registrant is performing or is assuming or purporting or has agreed to perform for himself or any other person ...." Id. §612(a)(6). The Act considers a "government of a foreign country" and a "foreign political party" to be principals. Id. $\S 611(\mathrm{~b})(1)$. A publicity agent is "any person who engages directly or indirectly in the publication or dissemination of oral, visual, graphic, written, or pictorial information or matter of any kind, including publication by means of advertising, books, periodicals, newspapers, lectures, broadcasts, motion pictures, or otherwise." Id. $\$ 611(\mathrm{~h})$.

Violation of the registration provision originally subjected the agent to a fine not in excess of $\$ 1000$ and/or a two-year prison term. Act of July 8, 1938, ch. 327, $\$ 5,52$ Stat. at 633 ; see also Note, Neutral Propaganda, supra note 10, at 439 n.23. The present version of the Act punishes failure to register with fines not in excess of $\$ 10,000$ or five years in prison, or both. 22 U.S.C. $\S 618$ (a)(2).

21. See, e.g., H.R. REP. No. 1470, 89th Cong., 2d Sess. 8-13 (detailing amendments that require disclosure of facts that indicate lobbying), reprinted in 1966 U.S. CODE CONG. \& ADMIN. News 2397, 2403-08.

22. The 1942 amendments were intended to remedy inadequate and inconsistent enforcenent of the original disclosure proeedures. See Note, Neutral Propaganda, supra note 10, at 440 \& nn.3234. Congress significantly changed the FARA by expanding the definitions of foreign principals and 
Meese v. Keene ${ }^{23}$ and Block v. Meese, a similar case decided by the D.C. Circuit, ${ }^{24}$ provided the initial opportunities for judicial review of the labeling requireinent called for in the Act; prior to these two cases, courts had only examined the disclosure and registration provisions. ${ }^{25}$ Lower courts have consistently upheld the disclosure provisions as valid exercises of congressional power to regulate foreign relations and protect national security. ${ }^{26}$ The Supreme Court, however, has never directly addressed the constitutionality of the Act's labeling requirement, and only

creating the definition for "political propaganda." Act of April 29, 1942, ch. 263, § 1, 1(b), (j), 56 Stat. 248, 249-51 (codified as amended at 22 U.S.C. $§ 611$ (1982)). Congress transferred the administrative responsibilities from the Secretary of State to the Attorney General. Id. § 2, 56 Stat. at 258 (codified as amended at 22 U.S.C. $\S \S 611$ note, 621 ). Most importantly, the labeling requirement was added. Id. $\S \S 1,4,56$ Stat. at 255 (codified at 22 U.S.C. $\S 614(\mathrm{a})$ ).

The 1966 amendments, Act of July 4, 1966, Pub. L. No. 89-486, 80 Stat. 244 (codified at 22 U.S.C. $\$ 611$ ), did not make significant changes in the filing and labeling provisions. See Note, Neutral Propaganda, supra note 10, at 442 (suggesting that Congress's failure to make adjustments implies satisfaction with the Act's form). Section 614 (a) and (b) now provide:

Every person within the United States who is an agent of a foreign principal and required to register under the provisions of this subchapter and who transmits or causes to be transmitted in the United States mails or by any means or instrumentality of interstate or foreign commerce any political propaganda for or in the interests of such foreign principal (i) in the form of prints, or (ii) in any other form which is reasonably adapted to being or which he believes will be disseminated or circulated among two or more persons shall, not later than forty-eight hours after the beginning of the transmittal thereof, file with the Attorney General two copies thereof and a statement, duly signed by or on behalf of such agent, setting forth full information as to the places, times, and extent of such transmittal.

It shall be unlawful for any person... . required to register under the provisions of this subchapter to transmit or cause to be transmitted ... any political propaganda ... unless such political propaganda is conspicuously marked at its beginniug with ... a true and accurate statement, in the language or languages used in such political propaganda, setting forth the relationship or connection between the person transmitting the political propaganda or causing it to be transmitted and such propaganda ....

22 U.S.C. $\S 614(\mathrm{a})$, (b).

While the disclosure/registration and fling/labeling sections of the FARA are distinct, they must be read in conjunction, since the labeling requirements apply only to principals required to register under section 612 of the FARA. See Note, Neutral Propaganda, supra note 10, at 442-43.

23. 481 U.S. 465 (1987).

24. Block v. Meese, 793 F.2d 1303 (D.C. Cir.), cert. denied, 478 U.S. 1021 (1986).

25. See, e.g., Attorney Gen. v. Irish People, Inc., 684 F.2d 928, 938, 942 (D.C. Cir. 1982) (focusing on registration distribution provisions, cert. denied, 459 U.S. 1172 (1983)); Attorney Gen. v. Irish Nat'1 Aid Comm., 530 F. Supp. 241, 260 (S.D.N.Y. 1981) (discussing specific registration requirements for foreign agents including listing of an address for the principal), aff'd, 668 F.2d 159 (2d Cir. 1982); Attorney Gen. v. Irish Nat'l Aid Comm., 346 F. Supp. 1384, 1390-91 (S.D.N.Y.) (disclosure provisions allow public to put political statements into appropriate context), aff'd, 465 F.2d 1405 (2d Cir.), cert. denied, 409 U.S. 1080 (1972); United States v. Peace Information Center, 97 F. Supp. 255, 263-64 (D.D.C. 1951) (upholding indictment of public relations counsel for failure to comply with registration procedures); United States v. Kelly, 51 F. Supp. 362, 363 (D.D.C. 1943) (act requires disclosure of source when articles published for compensation by foreign government, whether friendly or not); United States v. Auhagen, 39 F. Supp. 590,591 (D.D.C. 1941) (upholding indictment, indicating that Congress did not intend to deprive U.S. citizens of political information but to bring activities into the open and identify the source).

26. Peace Information Center, 97 F. Supp. at 259-60. 
once prior to Keene has the Court examined the disclosure and registration provisions of the FARA. ${ }^{27}$ In Viereck $v$. United States, the Court approved an imposition of criminal sanctions for failure to comply with the disclosure provisions (section 612) applicable to persons acting as agents of foreign principals. ${ }^{28}$ While dissenting on separate and unrelated grounds, Justice Black reiterated the view that FARA was not only constitutionally sound, but also promoted first amendment freedoms:

Resting on the fundamental constitutional principle that our people, adequately informed, may be trusted to distinguish between the true and the false, the bill is intended to label information of foreign origin so that hearers and readers may not be deceived by the belief that the information comes from a disinterested source. Such legislation inpleinents rather than detracts from the prized freedoms guaranteed by the First Amendment. 29

\section{B. Background of the Keene Labeling Controversy}

In January 1983, the National Film Board of Canada (the Board), a principal of the Canadian government, ${ }^{30}$ sought to distribute three motion pictures in the United States addressing the nuclear war and acidrain issues facing the United States and Canada. ${ }^{31}$ As a foreign principal, the Board was required to comply with the provisions of FARA. ${ }^{32}$ Before distributing any of its films, the Board, in compliance with the Act, submitted the materials intended for dissemination to the Depart-

27. See Viereck v. United States, 318 U.S. 236 (1943). The paucity of litigation may be attributed to a variety of factors, including the recent focus on political lobbying and the lack of a plaintiff with standing to assert first amendment rights. See supra notes 22-23 and accompanying text.

28. Viereck, 318 U.S. at 242.

29. Id. at 251 (Black, J., dissenting).

30. The National Film Board of Canada (NFBC), located in Ottawa, Ontario, is an agency of the government of Canada engaged in the "[p]romotion and distribution through commercial and non-commercial channels of Canadian Government information, documentary and cultural films, filmstrips, and other visual aid materials to public film libraries, educational institutions, government agencies, etc." Declaration of Joseph E. Clarkson, Chief of the Registration Unit, Internal Security Section, Criminal Division Department of Justice, Joint Appendix Exhibit B at 27, Meese v. Keene, 481 U.S. 465 (1987) (No. 85-1180). The NFBC (New York) is the agent for the NFBC in the United States and directs distribution in the United States. See Keene, 481 U.S. at 467-68 \& n.2.

31. The three films were entitled If You Love This Planet, Acid Rain: Requiem or Recovery, and Acid From Heaven. Keene, 481 U.S. at 468 n.3. The first film portrays the possible consequences of a nuclear holocaust. See Keene v. Smith, 569 F. Supp. 1513, 1515 (E.D. Cal. 1983), summary judgment granted sub nom. Keene v. Meese, 619 F. Supp. 1111 (1985), rev'd 481 U.S. 465 (1987). In 1983, the Academy of Motion Picture Arts and Sciences named the film best foreign documentary. Brief for Appellee, supra note 30, at 5. The other films concerned acid rain, or "the acidification of atmospheric precipitation by exposure to sulfur dioxide in the air." Keene, $569 \mathrm{~F}$. Supp. at 1515 .

32. See supra note 20. The NFBC (New York) has been registered with the Attorney General since 1947. Keene, 481 U.S. at 468 n.2. 
ment of Justice. ${ }^{33}$ On January 13, 1983 the Registration Unit of the Justice Department ${ }^{34}$ informed the Board that the three films had been classified as "political propaganda" 35 under FARA, and that a label disclosing the films' origin and the films' FARA registration would be required. ${ }^{36}$

Barry Keene, an attorney and majority leader of the California State Senate, had intended to exhibit the three labeled films to encourage discussion on the issues of nuclear war and acid rain. ${ }^{37} \mathrm{He}$ decided not to because he feared that his professional reputation and political career ${ }^{38}$

33. See supra note 22.

34. The formal designation is Registration Unit, Internal Security Section, Criminal Division, Department of Justice. 28 C.F.R. $\$ 5.100$ (1988). The Registration Unit is the designated enforcement board created by the Attorney General in accordance with his enabling powers under the FARA. See 22 U.S.C. § 620 (1982).

35. The term "political propaganda" includes any oral, visual, graphic, written, pictorial, or other communication or expression by any person (1) which is reasonably adapted to, or which the person disseminating the same believes will, or which he intends to, prevail upon, indoctrinate, convert, induce, or in any other way influence a recipient or any section of the public within the United States with reference to the political or public interests, policies, or relations of a government of a foreign country or a foreign political party or with reference to the foreign policies of the United States or promote in the United States racial, religious, or social dissensions.

22 U.S.C. $\S 611(\mathfrak{j})$.

36. For motion pictures, the requirement is satisfied by insertion of labeling frames at the beginning of the film. 28 C.F.R. $\$$ 5.402(e) (1988). The label reads as follows:

This material is prepared, edited, issued or circulated by (name and address of registrant) which is registered with the Department of Justice, Washington, D.C. under the Foreign Agent Registration Act as an agent of (name and address of foreign principal). Dissemination reports on this film are filed with the Department of Justice where the required registration statement is available for public inspection. Registration does not indicate approval of the contents of this material by the United States Government.

Complaint for Declaratory and Injunctive Relief at exhibit 1, Keene v. Smith, 569 F. Supp. 1513 (E.D. Cal. 1983) (No. CIVS-83-287-RAR), summary judgment granted sub nom. Keene v. Meese, 619 F. Supp. 1111 (1985), rev'd, 481 U.S. 465 (1987), reprinted in Joint Appendix, supra note 30, at 9, 16.

37. Keene, 481 U.S. at 467.

38. Id. at 473 (" $[\mathrm{H}]$ is personal, political, and professional reputation would suffer and his ability to obtain re-election and to practice his profession would be impaired." (quoting Keene, 569 F. Supp. at 1515)).

In support of his claims, Keene submitted a series of affidavits and evidence, including a 1984 public-opinion survey, designed and performed by the Gallup Organization, entitled Gallup Study of the Effect of Campaign Disclosures on Adults' Attitudes Toward Candidates. The pollster asked a national sample of adults how they would vote if informed that a candidate had arranged to show foreign filins that the Department of Justice had labeled as "political propaganda." Keene, 481 U.S. at $473-74 \mathrm{n}$. 7. The poll results indicated that $49.1 \%$ of the public would be less likely to vote for that candidate, $6.9 \%$ would be more likely to vote in his favor, $28.7 \%$ were indifferent. See Gallup Org., Inc., Gallup Study of the Effect of Campaign Disclosures on Adults' Attitudes Toward Candidates tbl. 3 (1984), reprinted in Joint Appendix, supra note 30, at 86.

Another declarant, Leonard W. Doob, Professor Emeritus of Psychology at Yale University and expert in the study of propaganda, concluded:

Designating material as "political propaganda," therefore, denigrates the material and stigmatizes those conveying it, in a manner that mere designation of the material as "political advocacy" would not. It is my professional judgment that knowledge of such a designation 
would be threatened by showing the labeled films, since the government would characterize him as a disseminator of propaganda. ${ }^{39}$ In March 1983, Keene brought suit in federal district court against the United States Attorney General ${ }^{40}$ and the Chief of the Registration Unit ${ }^{41}$ seeking to enjoin application of the labeling provision to the three films. ${ }^{42}$ The district court found the government's designation and label an abridgement of Keene's first amendment rights of expression. ${ }^{43}$ The court issued a prelininary injunction against the Attorney General ${ }^{44}$ and later granted the plaintiff's motion for summary judgment and permanent injunction. ${ }^{45}$ The government appealed directly to the United States Supreme Court. ${ }^{46}$

would be extremely likely to deter persons from viewing or reading such materials and, diminish and/or slant its communicative value, in a manner likely to make the reader or viewer suspicious of the material, far less likely to credit it or accept its conclusions.

Declaration (May 3, 1983), Block v. Smith, 583 F. Supp 1288 (D.D.C. 1984) (No. 83-0672), aff'd in part and rev'd in part sub nom. Block v. Meese, 793 F.2d 1303 (D.C. Cir.), cert. denied, 478 U.S. 1021 (1986), reprinted in Joint Appendix, supra note 30, at 100, 103, quoted in Keene, 481 U.S. at 474 n.8.

39. See 481 U.S. at 467 . Keene indicated that he intended to continue to exhibit the films, but only if the government was "enjoined from classifying the films as 'political propaganda." " Declaration of Barry Keene as regards having exhibited the three films (Nov. 23, 1983), Keene v. Smith, 569 F. Supp. 1513 (E.D. Cal. 1983) (No. CIVS-83-287-RAR), summary judgment granted sub nom. Keene v. Meese, 619 F. Supp. 111 (1985), rev'd, 481 U.S. 465 (1987) reprinted in Joint Appendix, supra note 30 , at 110. Although the label did not contain the term "political propaganda," the government's classification of the films as such undoubtedly would have been relayed to the public by the media or by political opponents. See Brief for Appellee at 14-17 \& n.15.

40. The original named defendant was William French Smith in his capacity as Attorney General. When Edwin Meese replaced Smith as Attorney General, the district court permitted substitution of the named party pursuant to Rule 25 of the Federal Rules of Civil Procedure. Keene, 619 F. Supp. at 1111 (E.D. Cal. 1985).

41. Keene, 569 F. Supp. at 1515-16. Joseph E. Clarkson, Chief of the Registration Unit, Internal Security Section, Criminal Division, United States Department of Justice, is the administrative and enforcement officer for the FARA. See supra note 34.

42. Both the speech and press clauses protect motion pictures. See Joseph Burstyn, Inc. v. Wilson, 343 U.S. 495, 502 (1952).

43. Keene, 569 F. Supp. at 1519-22.

44. Id. at 1523. The court found that Keene had standing to challenge the labeling requirement because he suffered a "distinct and palpable" injury in that the label characterized him as a purveyor of propaganda and adversely affected his reputation. Id. at 1518. Consequently, the plaintiff's first amendment freedom of speech was abridged when he was forced to choose between foregoing the exhibition of the films and risking the stigma created by the label. Id. at 1522. The court added that Congress, in enacting the FARA provisions, intended the term to be denigrating, id. at 1521-22, and that the government had offered no governmental interest sufficient to justify the restraint placed on the plaintiff. Id. at 1522 .

45. Keene, 619 F. Supp. at 1126.

46. See 28 U.S.C. $\$ 1252$ (1982) (providing for direct appeal to the Supreme Court from a district court's ruling holding an act of Congress unconstitutional), repealed by Act of June 27 , 1988, Pub. L. No. 100-352, 102 Stat. 662. 


\section{The Supreme Court's Decision in Meese v. Keene}

After concluding that State Senator Keene met the standing requirements to challenge the application of FARA's provisions, ${ }^{47}$ Justice Stevens, writing for the majority, ${ }^{48}$ inoved to an analysis of the first amendment issue -an analysis best described as a semantic tug-of-war. The governinent argued that the term "political propaganda," as used in section $611(j)$ of the Act, was a neutral term: any pejorative connotation attributed to "political propaganda" merely resulted from public misconception and misunderstanding. ${ }^{49}$ In response, Keene insisted that the label amounted to content-based censorship of the films. ${ }^{50}$ According to Keene, the Court in interpreting the statute should focus on the public's familiar perception of "propaganda" 51 because Congress itself intended to use a term of opprobrium to discourage dissemination. ${ }^{52}$

Unpersuaded by Keene's arguments, the Court distinguished the case from prior first amendment decisions by noting that Keene was not

47. To have standing a plaintiff must demonstrate (1) that he in fact has suffered, or will suffer, some injury; (2) that the injury can fairly be traced to the challenged conduct; and (3) that the injury can be, or likely can be, redressed by a favorable decision. Keene, 481 U.S. at 476 (citing Allen v. Wright, 468 U.S. 737, 751 (1984)); see also Valley Forge Christian College v. Americans United for Separation of Church \& State, Inc., 454 U.S. 464, 472 (1982).

The government argued that Keene's alleged injury was no more than the "chilling effect" on his freedom of speech from the "political propaganda" label. Brief for the Appellants at 12, Keene, 481 U.S. 465 (1987) (No. 85-1180). According to the government, a chilling effect from an official act is insufficient to confer constitutional standing. Id.; see also Laird v. Tatum, 408 U.S. 1, 13-14 (1972) (threat of an Army intelligence gathering program not a cognizable injury). The Court found that Keene alleged more than a "subjective chill"; he alleged his political reputation could suffer direct injury. Keene, 481 U.S. at 473; cf. Lamont v. Postmaster Gen., 381 U.S. 301,305 (1965) (requiring addressee to return a reply card before Postmaster General would deliver "communist political propaganda" was sufficient injury for standing purposes).

Second, Keene's injury was traceable to the Justice Department's enforcement of the statute. Keene, 481 U.S. at 476 (citing Simon v. Eastern Ky. Welfare Rights Org., 426 U.S. 26, 41 (1976)). Finally, the Court determined that the requested injunction would redress the threatened injury. 481 U.S. at 476-77. The Attorney General argued that the relief would not redress the alleged injury since Keene's constituents would continue to react to the initial "political propaganda" designation. Id. The Court, however, believed favorable relief would eliminate the need for Keene to choose between forgoing the exhibition of the film and facing the consequences of public reaction to the label. Id. at 477.

48. Justice Stevens was joined by Chief Justice Rehnquist and Justices White, Powell, and O'Connor. Keene, 481 U.S. at 466 . Justice Scalia did not participate, since he ruled in the related case of Block v. Meese, 793 F.2d 1303 (D.C. Cir.), cert. denied, 478 U.S. 1021 (1986), while sitting on the D.C. Circuit.

49. Brief for the Appellants, supra note 47 , at 31 n.24.

50. Keene, 481 U.S. at 478. See generally Police Dep't v. Mosely, 408 U.S. 92, 95 (1978) (restriction of speech based on "its message, its ideas, its subject matter, or its content" lies at the heart of first amendment prohibition).

51. Brief for Appellee, supra note 39, at 24-29.

52. Id. at 32-33. 
denied access to the films or prevented from disseminating them. ${ }^{53}$ The Court also pointed out that the filing/labeling provisions merely provided for the dissemination of additional information that would enable the public to evaluate the films more objectively. ${ }^{54}$ Indeed, the majority characterized the district court's injunction as a paternalistic measure that worked to shelter the public from information helpful to film evaluation. ${ }^{55}$ In the eyes of the Court, the injunction looked similar to state statutes that prohibited advertisement of prescription drug prices, which were declared unconstitutional in Virginia State Board of Pharmacy v. Virginia Citizens Consumer Council.56 The Keene Court reasoned that permitting distribution of labeled films furthered the protection of first amendment values: "By compelling some disclosure of information and permitting more, the Act's approach recognizes that the best remedy for misleading or inaccurate speech contained within materials subject to the Act is fair, truthful, and accurate speech." 57

While acknowledging the threat to Keene's reputation and career by his shorving of the labeled films, ${ }^{58}$ the Court concluded that, since the FARA definition had been on the books for over forty years, the public must have been aware that the term "political propaganda" was a neutral, statutory term of art. ${ }^{59}$ The Court thus refused to assume the public

53. Keene, 481 U.S. at 480 (distinguishing Lamont v. Postmaster Gen., 381 U.S. 301, 305-06 (1965), on grounds that Lamont involved detention of materials, not their mere designation as "communist political propaganda").

54. Id.

55. Id. at 481 .

56. 425 U.S. 748, 769-70 (1976) (statute violated first amendment because it presumed citizens benefited from "being kept in ignorance").

57. Keene, 481 U.S. at 481 ("Disseminators of propaganda may go beyond the disclosures required by statute and add any further information they think germane to the public's viewing of the materials.").

58. Id. at $473-74$.

59. Id. at 483. Both the district court and the Supreme Court, as well as the D.C. Circuit in Block, examined standard dictionaries and other reference sources for the popular definition of "propaganda." See, e.g., Webster's THIRD NEW INTERNational DictionaRY 1817 (1981) ("doctrines, ideas, arguments, facts, or allegations spread by deliberate effort through any medium of communication in order to further one's cause or to damage an opposing cause"), cited in Keene, 481 U.S. at 478 n.10. Other sources consulted give a more narrow, pejorative definition of "propaganda." See, e.g., WEBSTER's NEW World Dictionary Of THE AMERican LANGUage 1138 (2d College ed. 1976) ("now often used disparagingly to connote deception or distortion"); see also Keene, 481 U.S. at $478 \mathrm{n} .11$ (quoting earlier edition of Webster's New World Dictionary). Keene also submitted a declaration from Edwin Newman, a news correspondent for NBC and a member of the Usage Panel for the American Heritage Dictionary, explaining that political "propaganda" had become a "dirty word." Declaration (Apr. 28, 1983), Block v. Smith, 583 F. Supp. 1288 (D.D.C. 1984) (No. 83-0672), aff'd in part and rev'd in part sub nom. Block v. Meese, 793 F.2d 1303 (D.C. Cir.), cert. denied, 478 U.S. 1021 (1986), reprinted in Joint Appendix, supra note 30, at 107, 107-08. According to Newman, the public scrutinizes propaganda with suspicion and believes it to be biased 
was likely to construe the official designation in a pejorative sense, ${ }^{60}$ or that the public's "reaction[ ] . . . to the label 'political propaganda' would be such that the label would interfere with the freedom of speech."61

The Court also rejected the district court's position that "Congress' use of the term 'political propaganda' was 'a wholly gratuitous step designed to express suspicion with which Congress regarded the materials." 62 The Court emphasized that it would defer to Congress when interpreting statutory language ${ }^{63}$ and concluded that the term required a construction consistent with the neutral statutory definition. ${ }^{64}$

A dissenting opinion by Justice Blackmun took issue with several of the majority's conclusions. ${ }^{65}$ The dissent concluded that "regulations aimed at proper governmental concerns can restrict unduly the exercise of rights protected by the First Amendment," even if the Act's purpose was legitiniate and the definition was intended to be neutral. ${ }^{66}$ The dissent also insisted that the statutory definition could not be read in isolation from the effect of the label on the public opinion. 67 Justice Blackmun noted that in Lamont v. Postmaster General, 68 the Court held that the same term, "political propaganda," was "almost certain to have a deterrent effect" on speech. ${ }^{69}$ The dissenters also rejected the majority's analogy to Virginia Pharmacy Board, pointing out that the requested relief would not prevent the government (or any other person) from commenting on a particular film, but only would have prevented mandatory disclosure and labeling. ${ }^{70}$ They then likened the Act's disclosure and labeling requirements to certain disclosure statutes the Court

in favor of the profferor's special interests. Id., reprinted in Joint Appendix, supra note 30, at 107. 08.

60. Keene, 481 U.S. at $483-84$.

61. Id. at 482 .

62. Id. at 484 (quoting district court's opinion, $619 \mathrm{~F}$. Supp. at 1125).

63. Id.

64. Id. at 485.

65. Id. (Blackmun, J., dissenting in part). Justices Brennan and Marshall joined in the dissent.

66. Id. at 488 (quoting Minneapolis Star \& Tribune Co. v. Minnesota Comm'r of Revenue, 460 U.S. 575, 592 (1983)).

67. Id. ("A definition chosen by Congress is controlling as to the scope of the statute, but the Court has never held that Congress' choice of a definition precludes an independent determination of a statute's constitutionality based upon its actual effect."); see also id. at 489 ("it is the common understanding of the government's action that determines the effect on discourse protected by the First Amendment").

68. 381 U.S. 301 (1965).

69. Keene, 481 U.S. at 489 (Blackmun, J., dissenting in part) (quoting Lamont v. Postmaster Gen., 381 U.S. 301, 307 (1965)).

70. Id. at 493. 
had found unconstitutional on prior occasions. ${ }^{71}$ Finally, the dissent argued that the government could not identify a compelling interest in disseminating its characterizing information. ${ }^{72}$ Because the Justice Department had conceded that the label could be legally removed after it left the hands of the foreign agent, the actual informational value of the label was greatly reduced. ${ }^{73}$ The dissenters concluded that the governinent, rather than Keene, was gnilty of propagandizing. ${ }^{74}$

\section{A Constitutional Framework for Government SPeech}

A casual review of Keene suggests that the case involved a simple dispute over the proper definition of a statutory term. A lurking dissatisfaction remains, however, with the Court's deference to Congress and the Justice Department in its analysis of statutory interpretation. This dissatisfaction stems from the Court's failure to directly analyze important issues regarding government speech: neither the parties nor the Court identified the government's right to speak-through labelimg-as the critical issue. ${ }^{75}$ The identity of the speaker and the nature of the communication process arguably would have more impact on the constitutionality of the message than Congress's formulation of a statutory defimition.

This Note addresses directly the issue avoided by the Court in Keene: Where does government speech fit in the framework of first amendment doctrine? The Keene Court chose not to look at the question

71. Id. at 492. The cases cited include: Brown v. Socialist Workers ' 74 Campaign Comm., 459 U.S. 87 (1982) (compelled disclosure of campaign contributors and recipients of funds); Gibson v. Florida Legislative Investigation Comm., 372 U.S. 539 (1963) (compelled disclosurc of NAACP membership lists); Bantam Books, Inc. v. Sullivan, 372 U.S. 58 (1963) (statute authorizing state commission to designate morally objectionable materials); Talley v. California, 362 U.S. 60 (1960) (requiring names and addresses of authors and sponsors be placed on pamphlets for public dissemination); NAACP v. Alabama, 357 U.S. 449 (1958) (compelled disclosure of NAACP membership lists).

72. Keene, 481 U.S. at $493-95$ (Blackmun, J., dissenting in part).

73. Id. at 495. Joseph Clarkson, Chief of the Registration Unit, indicated that the Department of Justice had construed section 614(a) of the FARA and companion regulations to require only that the foreign agent insert the label; Keene, as a secondary recipient, could remove the label. Declaration of Joseph E. Clarkson, Chief of the Registration Unit, Internal Security Section, Criminal Division, Department of Justice, Joint Appendix, supra note 30, at 22.

74. 481 U.S. at 493 (Blackmun, J., dissenting in part) (classification of films uses government's "authority, presumed neutrality, and assumed access to all the facts" to reduce effectiveness of private speech).

It is the Government's classification of those films as "political propaganda" that is paternalistic. For that Government action does more than simply provide additional information. It places the power of the Federal Government, with its authority, presumed neutrality, and assumed access to all the facts, behind an appellation designed to reduce the Id.

effectiveness of the speech in the eyes of the public.

75. In fact, the Court expressly declined an opportunity to examine Congress's right to speak. Id. at 484 . 
in this way; this Note picks up the glasses set aside by the Court to focus on government speech, with the hope of reaching a more satisfying analysis. The discussion begins with a background of the current scholarship on government speech. ${ }^{76}$ After extracting a practical definition of

76. Professor Robert Kamenshine presents the most ambitious solution to the government speech problem by arguing that a political establishment clause should be implied from the first amendment. See Kamenshine, supra note 9, at 1104. But see Shiffrin, supra note 9, at 608-09 (maintaining that the "establishment clause is not serviceable for government speeeh"). Although previously rejected by the Supreme Court, the theory still receives some support. See Lathrop v. Donohue, 367 U.S. 820, 852 (1961) (Harlan, J., concurring) (rejecting proposal because of difference in wording between speech/press clauses and religion establishment clause, only the latter prohibiting "establishment"); accord Buckley v. Valeo, 424 U.S. 1, 93 n.127 (1976) (maintaining that "[t]he historical bases of the religion and speech clauses are quite different" and refleet the framers' great fear of government interference with religious worship); Joyner v. Whiting, 477 F.2d 456, 461 (4th Cir. 1973) (noting distinction between clause prohibiting establishment of religion and clause protecting freedom of press). The theory does not require per se invalidation of government communication, but rather a close examination: the government may speak only when it has an acceptable interest in doing so, and when the harm to individual expression does not outweigh that interest. See Kamenshine, supra, at 1125 . In practice the test would be similar to the three-part test under the religion establishment clause. See, e.g., Lemon v. Kurtzman, 403 U.S. 602, 612-13 (1971) (statute must have secular purpose, must neither advance nor inhibit religion, and must not foster excessive entanglement with religion).

The political establishment theory is both over-inclusive and under-inelusive. It forbids too much by preventing the government from even promoting democratic ideals that are essential for self-governance. See infra notes $125-35$ and accompanying text. It forbids too little by focusing on political speech. The dangers of government speech are present in all types of speech, and when the speech is not political, the government's justification for speaking might be insubstantial.

Thomas Emerson proposes a different model that would limit government speech rights to sub. ject matters over which the government traditionally has had authority. See T. EMERSON, THE SYSTEM OF FREEDOM OF EXPRESSION 699 (1970). The notion that Congress's exercise of its commerce power over state governments could be limited to areas not traditionally regulated by the state was rejected in Garcia v. San Antonio Metro. Transit Auth., 469 U.S. 528, 546-47 (1985) (rejecting the limitation because of difficulty of application). Applying a government funetion test in the area of freedom of speech should prove more manageable than in the commerce power area. While government function analysis under the commerce clause required difficult inspection of federalism concerns and historical uses of police powers, the analysis under the first amendment would require only a more familiar look at traditional separation of powers within the federal (or state) government.

To a certain extent this government function model reflects the argument that government speech should be limited to a purely informational role-a role traditionally fulfilled by the government. See infra notes 125-30 and accompanying text. The Massachusetts. Supreme Judicial Court relied on Emerson's argument in Anderson v. City of Boston, 376 Mass. 178, 195 n.16, 380 N.E.2d 628,639 n.16, appeal dismissed, 439 U.S. 1060 (1978), to sustain a challenge to the city's expenditures used to advocate ratification of an amendment to the state constitution. The government function model, however, breaks down when the expansion of necessary government services requires new types of communication. To avoid over-rigidity, the court would be forced into subjective line drawing between valid information and invalid advocacy.

Other commentators have suggested that courts focus on the extent to which the government communication drowns out other speakers' voices. See Shiffrin, supra note 9, (ultimately rejecting the model); see also F. HAIMAN, Speech and LAW IN A Free SocietY 429 (1981); L. Trine, AMERICAN CONSTITUTIONAL LAW $\$ 12-4$, at 807 (2d ed. 1988). When government speech cannot coexist with other speakers, it must be restrained. Cf. M. Yudof, supra note 9, at 94 (noting temp. 
"abridgment" from these sources, the discussion proceeds with an analysis of the competing interests both pro and con. This discussion will begin to develop a clearer picture of when government speech abridges individual speech and when the concern for effective, democratic selfgovernment would make such a restraint unconstitutional.

\section{A. Government Speech and the First Amendment}

Practitioners and academics traditionally have neglected the status of government speech in first amendment jurisprudence. ${ }^{77}$ Although some commentators have recognized this neglect-the Commission on Freedom of the Press, for imstance, in 1947 admitted the need for a better understanding of the government's role as communicator ${ }^{78}$-most first amendment analysis focuses on the private imdividual's freedom of expression. ${ }^{79}$ Some commentators have even contended that government speech does not enjoy first amendment protection at all. According to two such commentators, "[t]he problem of freedom of speech in the constitutional sense simply does not arise when the government itself is domg the speaking." 80 This conclusory analysis, however, really leaves the

tation to restrain government speech when government's voice is the only voice in the marketplace). The strength of the drown-out model is that it focuses on the overall communication process. The drown-out model correctly takes into consideration the dangers of a marketplace of ideas dominated by one speaker. See Shiffrin, supra note 9, at 601 . But like the establishment clause model, the drown-out model is both over-inclusive and under-inclusive. Id. at 600-01. Even if dissenting voices are still heard, government speech can improperly coerce the majority's consent. See infra notes 152-59 and accompanying text. On the other hand, the absence of other voices on a subject matter might simply reflect the government's unique access to information rather than a drowning out of individual voices.

Congress possesses several characteristics that make it particularly well-suited to address the dangers of government speech. The size of the body and autonomy of individual representatives usually prevent Congress from becoming a monolithic source of propaganda. See M. YuDof, supra note 9, at 181. More importantly, Congress depends on the majority for its existence; therefore, congressmen are more likely to respond to an existing consensus, rather than to try to make one. Id. at 180-81; see infra notes 152-59 and accompanying text (discussing dangers of coerced consent). Thus, Professor Yudof suggests that courts should focus on the existence of legislative endorsement of government communications. His separation of powers approach would encourage courts to protect government speech that has been authorized by the legislature. M. YUDOF, supra note 9, at 301. Deference to the legislative branch in the arca of government speech, however, is justified only if we can assume that the legislature is sensitive to the need to carefully screen non-informational elements from government speech. Recent examples of legislatively endorsed speech have undermined that assumption. When Congress enacted FARA it chose an arguably pejorative term for the label and then granted complete authority to a non-legislative branch to enforce the Act. Such congressional action hardly reflects a careful screening of non-informational elements.

77. See Z. ChAFEE, supra note 8, at 723; M. YUdoF, supra note 9, at 15-16.

78. Z. CHAFEE, supra note 8 , at 723 .

79. M. YUdof, supra note 9, at 16 .

80. J. Whitton \& A. Larson, Propaganda: Towards Disarmament in the War of WORDS 242 (1964). Whitton and Larson argue that political propaganda is a factor that aggravates world tensions. They conclude that the first amendment poses no obstacle to regulating directly U.S. 
issue unaddressed: government must talk to the governed, ${ }^{81}$ and the first amendment may provide guidelines for what the government can say.

1. The Textual Mandate of the First Amendment. The bluntest objection to government speech on constitutional grounds, is that the first amendment simply provides no protection for government speech. The text of the amendment certainly indicates that government speech cannot be equated with individual expression: the language expressly restrams the power of the government in favor of individual expression. ${ }^{82}$ On the other hand, the free speech and press clauses, unlike the free exercise and establishment clauses, do not bar government entanglement in matters dealing with expression in general. ${ }^{83}$ Consequently, the central question is not whether the government may engage in the expression of ideas-it can and must-but rather to what extent the government can express ideas without violating individuals' rights of free expression. The textual language of the first amendment without the gloss of judicial interpretation simply provides no answers to this question.

2. The Cases. The federal courts have done little to advance the sophistication of the debate on governinent speech and the first amendment. In Block v. Meese, then Judge Scahia, writing for the United States Court of Appeals for the District of Columbia Circuit, briefly addressed the issue of government criticism of individual expression in the context of another challenge to the Justice Department's film labeling decision. ${ }^{84}$ According to Judge Scalia, such criticism would not necessarily infringe

government communications. Id.at 242-43. For a critique of this view, see Van Alstyne, supra note 9, at 531-36.

81. See infra notes $125-37$ and accompanying text

82. See Anderson v. City of Boston, 376 Mass. 178, 191, 380 N.E.2d 628, 637 (1978) (first amendment restrains states from imposing barriers to individual expression), appeal dismissed, 439 U.S. 1060 (1978); Van Alstyne, supra note 9, at 532-33 (the first amendment is not an outright ban, but may require some restraint on government since it has the capacity to drown out the voices of individual expression). In the initial debates on the construction of the first amendment's text, Madison addressed the balance of power between the government and the people: "If we advert to the nature of Republican Government, we shall find that the censorial power is in the people over the Government, and not in the Government over the people." 4 ANNALS OF CoNG. 934 (1794) (statement of James Madison); see also West Virginia State Bd. of Educ. v. Barnette, 319 U.S. 624, 641 (1943) (" $[T]$ he Bill of Rights denies those in power any legal opportunity to coerce that consent. Authority here is to be controlled by public opinion, not public opinion by authority."); $c f$. THE FEDERALIST No. 52 (J. Madison) (preservation of liberty requires that the government be elected so it may be subject to public sympathy).

83. See Lathrop v. Donohue, 367 U.S. 820, 852 (1961) (Harlan, J., concurring) (clear distinction between speech and religion clauses, only the latter provides protection against establishment); Joyner v. Whiting, 477 F.2d 456, 461 (4th Cir. 1973) (noting difference in language of press and speech clauses and religion clause). But cf. Kamenshine, supra note 9, at 1109-13 (discussing the implied political establishment clause).

84. Block v. Meese, 793 F.2d 1303, 1312-14 (D.C. Cir.), cert. denied, 478 U.S. 1021 (1986). 
the individual's first amendment rights. ${ }^{85}$ To illustrate this point, he pointed out the inconsistency of the Constitution denying the governinent the right to speak on a subject (such as racial discrimination) but then allowing it to act directly on the same matter. ${ }^{86}$ Judge Scalia, quoting Professor Laurence Tribe, then concluded that government need not always reinain neutral, but may "add its own voice to the many it must tolerate." $87 \mathrm{He}$ added that a distinction between government and individual expression probably would prove unworkable because courts are not in a position to evaluate in each case whether the government is involved in a valid informational role or engaged in illegitimate advocacy. ${ }^{88}$

In Keene, the Supreine Court ignored the government speech question altogether by treating the government like any other individual speaker. The majority construed the labeling requirement as an information-enhancing provision, ${ }^{89}$ and characterized the district court's injunction as paternalistic and restrictive. 90 Of course in this case the characterization settled the issue: by finding that the label enhanced the public's information, the Court was led to the conclusion that the label requirement did not violate Keene's first amendment rights.

The discussions in both Block and Keene indicate that the federal courts are not disposed to tailor first amendinent analysis to account for the special problems of government speech. ${ }^{91}$ Maybe the reason is that

85. Id. at 1313.

86. Id.; $c f$. Posadas de Puerto Rico Assocs. v. Tourism Co., 478 U.S. 328, 345, 46 (1986) (the greater power to ban an activity outright (gambling), includes the lesser power to ban advertising of gambling casinos).

87. Block, 793 F.2d at 1314 (quoting L. TR1BE, AMER1CAN CONSTituTional LAw $\S 12-4$, at 590 (1978) (government may add its voice to the others it must tolerate as long as it does not drown them out)).

88. Id. at 1313 ("Th[e] distinction would raise the intolerable prospect of the courts' deciding what ideas are sufficiently popular to be grauted government support-the object being, presumably, to assure that only the ideas of insular minorities will suffer official disparagement."). Scalia seemed most concerned with this point.

89. See supra note 54 and accompanying text.

90. See supra note 55 and accompanying text.

91. Indeed, the notion that because certain speakers possess an unfair advantage in the communication market that justifies altering the traditional first amendment analysis has never received judicial approval. In Miami Herald Publishing Co. v. Tornillo, 418 U.S. 241, 258 (1974), the Court held unconstitutional Florida's right-of-reply statute enacted in response to the concentration of newspaper ownership. The Supreme Court dismissed the argument that the status of the speaker is relevant to its constitutional protection. Id. at 248-58; see also Buckley v. Valeo, 424 U.S. 1, 48-49 (1976) ("[T]he concept that government may restrict the speech of some elements of our society in order to enhance the relative voice of others is wholly foreign to the first amendment ....").

In First Nat'l Bank v. Bellotti, 435 U.S. 765 (1978), the Court reaffirmed this view: "[t]he inherent worth of the speech in terms of its capacity for informing the public does not depend upon the identity of its source, whether corporation, association, union or individual." Id. at 777 . In Bellotti, the Court held unconstitutional the State of Massachusetts' effort to prevent corporate entities from making statements about an election referendum not directly affecting their business inter- 
the courts are missing the subtle point at issue-wrestling with (maybe too) familiar first amendment analysis, the courts are missing the ramifications of government speech. To perliaps put too fine a point on it, Judge Scalia quoting Professor Tribe on the first amendment may slow that decisions in this area are not remedy-oriented nor a product of blatant judicial manipulation, but resort to such rhetoric clouds the issue and makes serious reflection on the implications of the FARA labeling requirement impossible. 92

\section{Individual and Societal Goals of Free Expression. Formulation} of a workable framework for reviewing government speech requires an examination of the purposes of free expression in a democratic society, in addition to an analysis of the first amendment and related cases. Traditional first amendment doctrine implicitly reflects a strongly held belief that a plurality of voices is desirable in the "marketplace of ideas."93 Moreover, a "robust, and wide-open" discussion of political affairs, the sine qua non of self-government, requires full freedom of expression. ${ }^{94}$ Indeed, this theme-more speech is better than less-was the inspiration for the Supreme Court's decision in Keene. ${ }^{95}$ A closer look at the goals served by the first amendment, lowever, reveals that more speech is not always better than less speech.

ests. Id. at 784. The statute amounted to a content-based restriction linked to the subject matter and the identity of the speaker. Id. at 784. The Court, however, hinted that the appellees failed to demonstrate that a corporate entity's influence and economic power tended to drown out the views of individuals. Id. at 789. Whether or not this model, see supra note 76 , would receive more than cursory treatment if adequately proven remains to be seen.

Justice White's dissent presented a very different perspective. He asserted that the State's interest in protecting individual expression from more powerful speech was derived from the first amendment itself. See Bellotti, 435 U.S. at 803-04 (White, J., dissenting). Therefore, two first amendment interests were in conflict because corporate speech was "not fungible" with individual expression and did not serve the same first amendment values as did individual expression. Id. at 804.

Bellotti may prove more helpful than its holding indicates. Justice White's dissent focusing on the importance and fragile nature of individual expression is a promising step forward. Moreover, the entire Court seemed to recognize that the processes of communication are more complex than traditional first amendment analysis recognized.

92. Cf. Note, The Appellate Jurisprudence of Justice Antonin Scalia, 54 U. CHI. L. REV. 705, 735 (1987) (suggesting that the Justice's unwillingness to grapple with difficult line-drawing in Block is inconsistent with his judicial philosophy of protecting minority interests).

93. See Abrams v. United States, 250 U.S. 616, 630 (1919) (Holmes, J., dissenting). Justice Brandeis's classic statement is likely the most quoted version of this utilitarian concept of free expression: "If there be time to expose through discussion the falsehood and fallacies, to avert the evil, by the processes of education, the remedy to be applied is more speech, not enforced silence." Whitney v. California, 274 U.S. 357, 377 (1927) (Brandeis, J., concurring).

94. New York Times v. Sullivan, 376 U.S. 254, 270 (1964); sec also Mills v. Alabama, 384 U.S. 214, 218 (1966); Garrison v. Louisiana, 379 U.S. 64, 74-75 (1964) ("[S]peech concerning public affairs . . . is the essence of self-government."); A. MEIKELJOHN, supra note 3, at 86-87.

95. See supra note 54 and accompanying text. 
The expansive reading that the courts have given the first amendment during the twentieth century resulted primarily from a need to protect the expression of minority views. Constitutionally protected freedom of expression guarantees that the minority elements in the marketplace of ideas will not lose their ability to be heard. Particularly when such minority views are not well-represented in the political process, free speech allows their expression even when they enjoy little support. ${ }^{96}$ The right to dissent and express diverse and unpopular viewpoints also promotes social utility by enriching public discourse and providing a soapbox from which radical and even revolutionary ideas can be aired (and forgotten or ignored). ${ }^{97}$ Most modern interpretations of the first amendment stem from this view that individual expression holds a high place in a free society.

Not all interpretations, however, focus on the rights to express minority views. Alexander Meikeljohn sees the first amendment's role as a guarantee of self-government.98 According to Professor Meikeljohn, freedom of expression helps to ensure that the government governs with the consent of the public, 99 and that the public-not the government-is in fact doing the consenting. ${ }^{100}$ Similarly, Mark Yudof emphasizes the first amendment's theme of majoritarian self-governance. ${ }^{101}$ Both Professors Meikeljohn and Yudof recognize that the effectiveness of selfgovernance is inevitably influenced, if not controlled, by the information and views to which the public is regularly exposed (including the views of the government). ${ }^{102}$ As the level of government communication increases, the public's reliance on government information also increases, and the implications of such speech for democratic self-governance multiply. ${ }^{103}$ Thus, because the first amendment promotes self-government

96. M. YUDOF, supra notc 9, at 146. Historically, such "fringe elements" have provided critical tests of the first amendment's scope. See, e.g., Brandenburg v. Ohio, 395 U.S. 444 (1969) (the Ku Klux Klan); Aptheker v. Secretary of State, 378 U.S. 500 (1964) (Communist Party of America); NAACP v. Alabama, 357 U.S. 449 (1958) (Black Americans); Cantwell v. Connecticut, 310 U.S. 296 (1940) (Jehovah's Witnesses); Gitlow v. New York, 268 U.S. 652 (1925) (Socialist Party).

97. Abrams, 250 U.S. at 630 (Holmes, J., dissenting); Finman \& Macaulay, supra note 9, at 680-86.

98. A. MeIKeuohn, supra note 3, at 10-11.

99. See id. at 12-16.

100. See id.; cf. CBS, Inc. v. Democratic Nat'l Comm., 412 U.S. 94, 148-49 (1973) (Douglas, J., concurring) (first amendment adopted to ensure functional democracy and to protect against factions in government forcing their views on the public).

101. M. YUDOF, supra note 9 , at 141 (discussing need to eliminate dichotomy between minority and majoritarian concerns in first amendment analysis).

102. A. Meikeluohn, supra note 3, at 65-68; M. YUDof, supra note 9, at 46.

103. Z. ChaFEE, supra note 8 , at 13.

The power of governments over the sources of information tends to grow. Hence the misuse of this power by governments becomes a more and more serious danger. Governments withhold one part of the facts and use the other for sales talk. This tendency is fostered by 
by eliciting public consent, a valid interpretation of the amendment requires that government speech be protected if it enhances self-governance and aids the public in decisionmaking. ${ }^{104}$ Building on the foundation laid by professors Meikeljohn and Yudof, the next subsection presents a series of scenarios in which government speech would not enhance selfgovernance and thus arguably would not be protected speech under the first amendment.

4. Defining an Abridgment of Individual Expression. Censorship is not the only inanner by which the government might abridge speech. ${ }^{105}$ Indeed, in some circumstances government expression itself might so dominate individual expression as to meet the constitutional paradox: when is more speech actually less speech? To conceptualize types of government speech that might restrain individual expression, I will describe an imaginary society called Miltonia. Although not completely divorced from the Anglo-American legal tradition, the Miltonia Constitution assumes no protection like the first amendment for an individual's right to speak. Given the absence of a free speech guarantee in Miltoma, I will explore how, short of plysical force, a government might control undesirable speecl.

Unconstrained by a free speech guarantee, the Miltonian government would have several options available to silence an unwelcome pamphleteer who, for exainple, publicly criticizes government action. The government could enact a licensing scheme and then deny the pamphleteer's request for a license to publish his ideas. The government also could impose fines or imprisonment for seditious publications, or enjoin the publication of unpopular stories. Moreover, it could grant civil remedies to those who are libeled or whose privacy rights have been infringed.

\footnotetext{
general worship of efficient salesmanship. ... Even when completely devoid of such intentions to falsify and propagandize, governments must make increasing use of communications.

Id.

104. Thus, the critical factor in distinguishing proper and improper government speech is whether the commumication can be characterized as informational or promotional. The Supreme Court made this distinction in Talley v. California, 362 U.S. 60 (1960), when it struck down a local ordinance that required pamphleteers to include identification labels on their handbills. The Court noted the right to speak anonymously, id. at $64-65$, but a critical factor in the decision appeared to be the state's failure to show a compelling interest in requiring the information. Id. at 66 (Harlan, J., concurring). Thus, the purpose of government speech is a significant factor in determining when the government can properly speak.

105. Prior to the developments in this century, even ardent supporters of broad first amendment protections did not construe freedom of expression far beyond the Blackstonian view of protection from prior restraints. See J. Nowak, R. Rotunda \& J. Young, Constitutional LAW § 16.5 (3d ed. 1986). While freedom from prior restraints continues to be a primary goal of the first amendment, see Near v. Minnesota, 283 U.S. 697, 713 (1932), the concept of an abridgement has gradually expanded to include more than censorship.
} 
Besides such direct action, the government might place restraints on the pamphleteer's speech through a variety of regulatory schemes: for instance, it could heavily tax newsprint; enact a zoning ordinance prohibiting printing presses; or require costly licenses for delivery vehicles.

Another alternative for the Miltonian government would be to effectively burden the pamphleteer through more subtle devices. For example, it could enact a disclosure law requiring the pamphleteer to release the names of his financial supporters and political allies. The government also could force the pamphleteer to devote reasonable space in his publication to opposing viewpoints. Not unlike the more direct restraints mentioned above, these devices impose a cost on the painphleteer and his supporters in terins of free expression by threatening their autononiy and anonymity. The more subtle devices differ, though, in that the subtle devices mandate the inclusion of more information without affecting the content of the pampleteer's own speech or punishing it. Thus, the government of Miltonia could take action, under the guise of enhancing information, that actually restrains individual expression.

Finally, the Miltonian government could publish its own paper, responding to the pamphleteer's statements, and criticize the pamphleteer himself, advise the public to ignore hin, or even encourage the public to boycott him. Like the other devices to restrain the pamphleteer, the government communication and corresponding public reaction would impose certam costs on the pamphleteer. He may experience public scorn; moreover, a widely distributed government paper might overwhelm his message, or the government's response might burden his message. Under these circumstances, the government is providing more information with one hand while in essence reducing or diluting information with the other.

None of these scenarios establishes that any time government speaks it unconstitutionally restrains individual expression. An examination of the choices available to the Miltonian government, however, indicates that governnent speech can burden or restrain individual expression in some situations. When that happens, the government undermines a priinary goal of the first amendment: the promotion of democratic selfgovernance.

\section{B. A Need for Government Speech}

The Constitution does not condemn every restraint on individual expression, and the courts, as interpreters of the first amendment, always have been sensitive to situations that require a certain annount of restraint 
to preserve our system of ordered liberty. ${ }^{106}$ For each identified category of speech, the Supreme Court has struggled to develop a doctrine that properly balances the interest in protecting that speech with the interest (frequently of the government) in regulating or restraining it. ${ }^{107}$ Thus, a constitutional framework for government speech requires an evaluation of the competing interests of promoting and restraining government speech in addition to a definition of restraint. This section presents some of the benefits created by government speech, whereas the next section addresses the adverse effects of unrestrained government speech.

Even those who staunchly advocate limits on government speech recognize that government should play a positive role in the process of communication. ${ }^{108}$ People require vast amounts of information to govern themselves effectively, and they increasingly rely upon the modern bureaucracy to provide that information. ${ }^{109}$ Often government, because of its unique access to and ability to manage and process data, provides information that no other entity can provide. ${ }^{110}$ In the case of the Foreign Agents Registration Act, Congress, with its singular power to provide for national security and regulate foreign principals, enacted a disclosure statute to make information available to the public that otherwise might not have been available. ${ }^{111}$

In addition to its role in providing information, government also engages in a certain amount of socialization or inculcation of democratic values. ${ }^{112}$ The government thus strengthens the prospects for self-government through the promotion of democratic ideals. ${ }^{113}$ From the time

106. See, e.g., Yates v. United States, 354 U.S. 298, 319-20 (1957) (advocacy of forcible overthrow of the government); Chaplinsky v. New Hampshire, 315 U.S. 568, $572-73$ (1942) ("fighting words" doctrine).

107. See generally Konigsberg v. State Bar, 366 U.S. 36, $49-51$ (1961) (attempt to balance interests in the context of questions concerning Communist Party membership).

108. See T. EMERSON, supra note 9, at 698 (Government involvement "is a necessary and healthy part of the system"); J. TusSMAN, supra note 9, at 3-13 (government has role in shaping "mind" of the public); Ziegler, supra note 9, at 604 (government expression is both necessary and proper). Citizens may even possess an affirmative right to have communications from the government. Z. CHAFEe, supra note 8, at 723-24; F. HAIMAN, supra note 76, at 410.

109. See Z. ChafeE, supra note 8 , at 723.

110. M. Yudof, supra note 9, at 46; cf. Citizens to Protect Pub. Funds v. Board of Educ., 13 N.J. 172, 178-80, 98 A.2d 673, 676-77 (1953) (school board has valid interest in providing full disclosure of the details of school building program prior to referendum on issue).

111. See Note, Foreign Political Propaganda, supra note 10, at 1404-05 (mail wrapper identifies origin of foreign "propaganda"; FARA identifies resident alien "propaganda").

112. See M. YUDOF, supra note 9, at 111-13.

113. Id. Judge Scalia echoed this democratic ideal in his Block opinion. He argued that permitting government to prohibit racial discrimination, criminalize polygamy, and make war on Nazi Germany, but not permitting it to criticize doctrines or praise contrary values is a "strange conclusion." Block v. Meese, 793 F.2d 1303, 1313 (D.C. Cir.), cert. denied, 478 U.S. 1021 (1986). He noted that a state's selection of textbooks and course curriculum is a "forceful and influential expres- 
children enter public schools, government exposes its citizens to democratic values and the workings of the American system. ${ }^{114}$

One point should be emphasized, though: this process of inculcation of democratic values differs from the process of indoctrination. While indoctrination promotes particular viewpoints, the socialization promotes toleration and participation, and encourages citizens to exercise their first amendment rights. ${ }^{115}$ According to Professor Yudof, the government legitimizes its claim to power through the consent of the public, and that is achieved by encouraging unfettered individual expression and plurahism. ${ }^{116}$

The proper limits on the government's affirmative role in the communication process elude a generahzed definition. "The power to teach, inform, and lead is also the power to indoctrinate, distort judgment, and perpetuate the current regime."117 Obviously, some types of government speech might merely sustam the status quo. Nevertheless, the government is uniquely able to provide certain information and promote certain ideals that our system of democratic self-governance demands for its continued existence.

sion of official approval and disapproval of ideas." Id. Scalia is undoubtedly correct when he says that all government actions and legislation promote some type of ideology or philosophy. The equivalency he draws between speech and action, however, seems questionable.

114. Selection of student curricula and textbooks is a common example of the govenment's role as communicator. The selection typifies the dilemma of government speech-a valuable form of government communication that inevitably promotes certain viewpoints and ideologies. See Kamenshine, supra note 9, at 1132-38 (advocating limitation on this type of promotion); Shiffrin, supra note 9 , at $568,647-53$.

115. Justice Jackson's famous remarks highlight the improper government role: "If there is any fixed star in our constitutional constellation, it is that no official, high or petty, can prescribe what shall be orthodox in politics, nationalism, religion, or other matters of opinion or force citizens to confess by word or act their faith therein." West Virginia State Bd. of Educ. v. Barnette, 319 U.S. 624, 642 (1943) (Jackson, J.).

Professor Yudof offers a circular distinction between the two concepts: socialization produces a self-controlled citizenry capable of resisting indoctrination. M. YUDOF, supra note 9, at 112. More precisely, socialization is viewpoint neutral. It promotes listening to and tolerating all viewpoints and allowing the citizen to make judgments on the merits. On the other hand, indoctrination is not viewpoint neutral and promotes passive acceptance of those viewpoints. But cf. Carter, Evolutionism, Creationism, and Treating Religion as a Hobby, 1987 DukE L.J. 977, 985-96 (traditional concept of tolerance permits "official indoctrination in a philosophy that runs contrary to deeply held religious beliefs").

116. M. YUDOF, supra note 9, at 176-77. Therefore, the government must remain a referee, compensating only for the imbalances in the ideological marketplace. Id. at 92-93. When government communicates regularly, or has its own agenda to carry out, remaining in that referee's role might prove difficult. See id. at 93.

117. $I d$. at 42 . 


\section{The Undesirable Effects of Government Communication}

The variety of factors peculiar to each instance of government communication, and the divergence of its actual effect from the impact the government intended, make it virtually impossible to predict the precise effect of government expression. ${ }^{118}$ Several general characteristics of government speech, however, prevent the communication process from functioning properly. This section will analyze those characteristics and their impact on the majority and minority elements in the ideological marketplace.

1. Effect on the Majority. In general, the public displays great respect for government communications. ${ }^{119}$ Such publications exude legitimacy because they bear the imprimatur of the government, inscribed with its authority and prestige. ${ }^{120}$ When the public perceives the government as having expert knowledge of an issue or unrivaled control over a matter, the government communication may command even greater respect and faith. ${ }^{121}$ Respect for the government, reliance on the accuracy of its statements, and fear of challenging its authoritative word might cause citizens to withdraw, to a certain extent, from their duties of selfgovernance. ${ }^{122}$ As a result, government would coerce, rather than earn, the majority's consent. ${ }^{123}$ The coercive effect may be compounded as public opinion begins to consolidate and dissenters, intimidated by the government's authoritative voice, refrain from speaking. The effect would be to create an aura of infallibility around government speech ${ }^{124}$ and an environment arguably conducive to indoctrination. ${ }^{125}$

Government speech that forces a captive audience to be subject to a

118. Id. at 71-72; cf. Minneapolis Star \& Tribune Co. v. Minnesota Comm'r of Revenue, 460 U.S. 575, 592 (1983) (regulations that have proper purposes may result in undue restriction of first amendment freedom).

Yudof devotes a section of his book to a review of various studies undertaken by the social sciences on the audience impact of both interpersonal and mass communications. M. YuDof, supra note 9, at 70-89 (theories inadequate to account for the numerous factors determining impact of communication, such as social status, class, gender, race, beliefs, personality, prejudices, maturity, and nature of the message).

119. See T. EMERSON, supra note 9, at 698.

120. M. YuDof, supra note 9 , at 156 (prestige and status of the government give it an advantage in communication).

121. Id. at 156.

122. Id.

123. See id. at 94; Note, Government Speech, supra note 9, at 833-34.

124. Note, Government Speech, supra note 9, at 833-34.

125. M. YuDoF, supra note 9, at 157. Indoctrination is likely to result when "[t]he message is so distorting of judgment, the government's access to information so unique, and the point of action or judgment so close in time that contrary messages will be of no avail." Id. at 94. 
particular viewpoint presents the clearest example of coerced consent. ${ }^{126}$ The Supreme Court generally has expressed disdain for such measures. For example, in Wooley v. Maynard, the Court held unconstitutional New Hampshire's prosecution of a Jehovah's Witness for concealing the motto "Live Free or Die" displayed on his automobile license plate. ${ }^{127}$ Although the Jehovah's Witness objected on religious grounds, ${ }^{128}$ the Court framed the issue as one involving the first amendment right not to be forced to bear a state message. ${ }^{129}$ The Court reasoned that, although the government may promote an ideological viewpoint, it must rely on the merits of its statements rather than its imstitutional power to obtain the majority's consent. ${ }^{130}$

Examples of less direct forms of coercion abound, and the Supreme Court has not ignored them. In Pacific Gas \& Electric v. Public Utilities Commission, the Court reviewed the State of Califorma's requirement that a utility company make available to public interest groups excess space in a monthly customer newsletter. ${ }^{131}$ The Court held that the requirement was unconstitutional, explaining that, despite the State's interest in providing full information to the public, "the State cannot advance some points of view by burdening the expression of others." 132 The danger of coercion thus exists, not only when the government forces a person to speak against his will, but also when it burdens the speaker's ability to communicate. ${ }^{133}$

Coerced consent also might take the form of the government advocating its own perpetuation. Self-perpetuation simply is not the government's job.134 The dissenting taxpayer cases illustrate this form of coercion. ${ }^{135}$ Typically individuals complain that the government, utiliz-

126. See Van Alstyne, supra note 9, at 534; see also Public Utils. Comm'n. v. Pollak, 343 U.S. 451, 467-69 (1952) (Douglas, J., dissenting) (government may not force its message on an unwilling audience); West Virginia Bd. of Educ. v. Barnette, 319 U.S. 624, 640-42 (1943) (government may not coerce uniformity of sentiment).

127. 430 U.S. 705 (1977).

128. Id. at 707 .

129. Id. at 715 .

130. Id. at 717.

131. 475 U.S. 1, 6-7 (1986).

132. Id. at 20 (citing First Nat'l Bank v. Bellotti, 435 U.S. 765, 785-86 (1978)).

133. This "piggybacking" harm was addressed in Miami Herald Publishing Co. v. Tornillo, 418 U.S. 241 (1974). In Miami Herald, the Court held unconstitutional a Florida statute requiring a right-of-reply to newspaper editorials. The Court stressed the burden on free speech imposed when the editors of the paper were compelled to publish what they would not choose to publish voluntarily. Id. at 256.

134. T. EMERSON, supra note 9, at 699.

135. For an in-depth discussion of the taxpayer cases, see Shiffrin, supra note 9, at 589-95; Ziegler, supra note 9, at 614-17; see also Note, The Constitutionality of Municipal Advocacy in Statewide Referendum Campaigns, supra note 9, at 545-53. 
ing public resources, advocates a particular viewpoint on an issue that must be decided ultimately by the public. ${ }^{136}$ This position admits that the government validly may spend funds to provide relevant public information ${ }^{137}$ or encourage civic participation, ${ }^{138}$ but it cannot spend funds to advocate a position on an election issue. ${ }^{139}$ When government campaigns for its own interests, it "endow[s] that campaign with all of the prestige and infuence naturally arising from any endorsement of a governmental authority." 140 Such endorsements may result in the public withdrawing from its decisionmaking role and automatically granting its consent to the government's position.

2. Effect on Minority Elements. In addition to undermining the political role of the majority in society, government speech also inhibits the expression of dissenting opinions. The thought of confronting a government position often causes speakers to "think twice" before speaking out in opposition. ${ }^{141}$ Then Judge Scalia, apparently ignoring this proposition, coinmented in Block that "[i]f the first amendment considers speakers to be so timid, or important ideas to be so fragile, that they are overwhelmed by knowledge of governmental disagreement, then it is liard to understand why official governmental action, ... . does not constantly disrnpt the first amendment 'inarketplace." 142 While Scalia's logic is intuitively appealing, it misses an important characteristic of government speech that distinguishes it from government action.

136. See, e.g., Mountain States Legal Found. v. Denver School Dist., 459 F. Supp. 357 (D. Colo. 1978) (school board urging defeat of state constitutional amendment on spending); Stanson v. Mott, 17 Cal. 3d 206, 551 P.2d 1, 130 Cal. Rptr. 697 (1976) (parks and recreation department urging approval of parks bond issue); Anderson v. City of Boston, 376 Mass. 178, 380 N.E.2d 628 (1978) (city supporting constitutional amendment), appeal dismissed, 439 U.S. 1060 (1979); Citizens to Protect Pub. Funds v. Board of Educ., 13 N.J. 172, 98 A.2d 673 (1953) (Brennan, J.) (school brochure advocating public school building program); Stern v. Kramarsky, 84 Misc. 2d 447, 375 N.Y.S.2d 235 (Sup. Ct. 1975) (state government advocating passage of Equal Rights Amendment).

137. E.g., Stanson, 17 Cal. 3d at 209-10, 551 P.2d at 3, 130 Cal. Rptr. at 699 (court held that Department of Parks and Recreation had the authority to disseminate "information" to the public relating to a bond election but had to do so in a fair presentation of relevant facts and not just to promote themselves).

138. Stern, 84 Misc. $2 d$ at 452,375 N.Y.S.2d at 239.

139. E.g., Mountain States Legal Found., 459 F. Supp. at 360-61.

140. Stern, 84 Misc. $2 d$ at 450,375 N.Y.S.2d at 237.

141. Finman \& Macaulay, supra note 9, at 633. In one of the earliest works to discuss the adverse consequences of government speech, Finman and Macaulay examined the government's public criticism of those protesting the nation's involvement in the Vietnam War. They concluded that while the government did have certain first amendment rights, $i d$. at 695, government criticism of citizens' expression may violate the spirit of the amendment, $i d$. at 679 . Ultimately, the authors stressed the importance of self-restraint as a more effectivc curb on improper government speech than judicially imposed limits. Id. at 694, 706-07.

142. Block v. Meese, 793 F.2d 1303, 1313 (D.C. Cir.), cert. denied, 478 U.S. 1021 (1986). 
The problem with government speech is that its effects are often subtle and deceptive. For example, when government acts directly, it does so under public scrutiny and such action is subject to public recall through the political process. But when the government uses speech to criticize or influence individual expression, it might be restraining expression indirectly that it has no authority to restrain directly. Thus, government speech can inhibit minority expression, even when direct restramt would be unconstitutional or politically unacceptable. ${ }^{143}$

The expression of minority viewpoints suffers as a direct result of the majority's reaction to those viewpoints. ${ }^{144}$ By simply garnering strong support from the inajority, the government can intentionally, or unwittingly, silence dissenters through the minority's natural apprehension of majority disdain. For example, when the American government encouraged public support of the war in Vietnam, the public, in turn expressed its disdaim of opponents to the war by attacking them. ${ }^{145}$ On the other hand, if the government withholds its communication (for whatever reason) and the issue before the public is considered a "close call," then dissenting views are less likely to feel disdain and, consequently, more likely to be expressed.

The Supreme Court has recognized that indirect government restramt of minority views might violate the first amendment. ${ }^{146}$ In Bantam Books, Inc. v. Sullivan, a local government commission compiled a list of distributors of offensive books, and released this list to the public. ${ }^{147}$ Although the government did not directly restram speech in this case, the Court found that the public's likely reaction to the list would inhibit the distributors' expression. ${ }^{148}$ The Court held that the causal connection between the list and public reaction was sufficient to conclude that the government communication abridged the distributors' first

143. Under current first amendment doctrine, as used in Keene, the government need not meet any judicial test in order to disseminate its message.

144. See, e.g., Lamont v. Postmaster Gen., 381 U.S. 301, 307 (1965) (noting the inhibition felt by person requesting mail considered by government to be propaganda); Communist Party of the United States v. Subversive Activities Control Bd., 367 U.S. 1, 141 (1961) (Black, J., dissenting) (statute required warning about the "treasonable nature" of communist organizations which inhibited registration of members into the Communist Party because of fear of disgrace, humiliation and imprisonment).

145. See Finman \& Macaulay, supra note 9, at 693-94; see also supra notes 119-25 and accompanying text (discussing government's ability to coerce majority's support).

146. See, e.g., Bates v. City of Little Rock, 361 U.S. 516, 523-24 (1960) (compulsory disclosure of NAACP membership lists unconstitutionally interferes with freedom of association); NAACP v. Alabama, 357 U.S. 449, 463 (1958) ("The crucial factor is the interplay of governmental and private action, for it is only after the initial exertion of state power represented by the production order that private action takes hold.").

147. 372 U.S. $58,71-72$ (1963).

148. Id. at $66-67$. 
amendment rights. ${ }^{149}$

3. Effect on the Ideological Marketplace. All properly functioning markets, including, arguably, the ideological marketplace, exhibit at least two essential characteristics: (1) all participants possess comparable bargaining power, and (2) all participants possess complete knowledge of the products offered in the market. ${ }^{150}$ These characteristics tend to disappear from the ideological marketplace, however, when the government speaks. The governinent enters the market with a tremendous bargaining advantage so that its perceived authority often drowns out other speakers. ${ }^{151}$ As Professor Haiman stated, "[T] he critical issue ... is not so much whether the government speaks but whether others are able to talk back, and to do so with a fighting chance of prevailing." 152

Furthermore, the public rarely knows enough about governinent speech to determine who, within the government as a whole, is actually responsible for any particular communication. Many commentators agree that the impact of a message depends on the identity of the speaker. ${ }^{153}$ But the public will encounter difficulty determining whether a communication originated fron a relatively low-level government official, a more responsible official, a deliberative body, or a non-deliberative body. ${ }^{154}$ Determining the source of the coinmunication would be difficult since individual officials often fail to distinguish their own views in the information published under the government's authority. ${ }^{155}$ A single Justice Department official, for example, determined that the three Canadian films were "propaganda" as defined in the Foreign Agents Registration Act; but one must question whether the general public would be sensitive to the possibility that the labels might owe their existence simply to the bias (political, cultural, or literary) of one governınent

149. Id. at 71.

150. P. SAMuelson, Economics 60-62 (11th ed. 1980).

151. See M. Yudof, supra note 9 , at 94 .

152. F. HAIMAN, supra note 76, at 421; see also L. TR1BE, supra note $76, \S 12-4$, at 807.

153. See M. YuDoF, supra note 9, at 77 . Yudof emphasizes four factors in evaluating any message's impact: (1) the characteristics of the communicator; (2) the content of the message; (3) the characteristics and dispositions of the audience; and (4) the response of the audience. Id.

154. Cf. Kamenshine, supra note 9, at 117 (distinguishing between speech from an individual government official and speech from a government institution). Complicating the issue is the fact that government personnel have certain first amendment rights to speak in their individual capacity. See United States Civil Serv. Comm'n v. National Ass'n of Letter Carriers, 413 U.S. 548, 564-68 (1973); cf. Ziegler, supra note 9, at 606 (personal political speech protected, but when it becomes government conduct using government resources protection is lost).

155. See Z. ChafEe, supra note 8, at 762-64 (difficult to keep self-interest and individual political views out of government communication). 
bureaucrat. ${ }^{156}$

\section{Summary}

In Block v. Meese, Judge Scalia asserted that the complexities of analyzing the impact of government speecl and the difficulty of drawing lines between proper and illegitimate government speech made such analysis "intolerable."157 While recognizing that the difficulties are substantial, the preceding discussion suggests that a manageable framework of analysis for government speech can be constructed. In many cases, the framework will prove difficult to apply, but no more or less difficult than our already highly specialized and imterpretive first amendment doctrine. Courts must attempt to determine whether government speech restrains individual expression in a particular case, and then whether the negative effects of that commumication outweigh its positive effects.

\section{ANOTHER LOOK AT KEENE}

The final part of this discussion will test FARA's labeling provision against the framework for government speech developed in the previous part by evaluating whether the official designation of the films as "political propaganda" actually restramed individual expression, and whether the label's negative effects on society outweigh its positive effects. This framework will help focus a court's analysis and, as shown below, could lead future courts to find that the FARA labeling provision violates the first amendment. While not always leading to protection of individual's freedom of expression, the framework ensures that courts consider the serious imphications of the government as communicator.

\section{A. Restraint}

The government in Keene maintained that the official label on the films used neutral termmology, and that any negative connotations must

156. A career Justice Department employee with about ten year's experience in the Registration Unit reviewed the films and decided whether to label them. Brief of the American Civil Liberties Union, Mitchell Block, as President of Direct Cinema Limited, Inc., Amici Curiae, in Support of Appellee, Meese v. Keene, 481 U.S. 465, app. at B-6 (Statement of D. Lowell Jensen, Assistant Attorney General, Criminal Division, Department of Justice, before the House Committee on the Judiciary, Subcommittee on Civil and Constitutional Rights, Concerning the Foreign Agent Registration Act of 1938, as amended on March 18, 1983) ("process necessarily involves some discretion and expertise, primarily a sensitivity to the leading political themes of the day"); see also Note, Neutral Propaganda, supra note 10, at 461 (determination made by Justice Department career attorneys, "based primarily on common sense") (quoting Peterson, Canada Asks State Department to Reverse Decision on 3 Films, Wash. Post, Feb. 26, 1983, at A2, cols. 13 (quoting Justice Department statement released by a spokesman, Thomas P. DeCair)).

157. 793 F.2d 1303, 1313 (D.C. Cir. 1986), cert. denied, 478 U.S. 1021 (1986). 
be attributed to public misunderstanding. 158 The Court agreed with the government's position without questioning whether the general public was even aware of Congress's statutory definition of "propaganda."159 If evaluated within the proposed framework for government speech, however, the government's argument appears to rest on a critical misunderstanding of the communication process. ${ }^{160}$ Since government derives its power solely from the consent of the public, then the substantive content of government speech also should refiect public sentiment; otherwise, a government would theoretically be engaged in forming public consent rather than respondimg to it. ${ }^{161}$ But the government, with a powerful voice and presumed authority, has the potential to subject Keene to public scorn and impose a substantial cost on his expression. ${ }^{162}$ The deterrent effect created by the label, although not a direct restraint on Keene's expression, ${ }^{163}$ actually caused Keene to abandon his plan to show the films. ${ }^{164}$ The labeling provision thus presents a useful example of how more speech can create less speech, when government speech is at issue. ${ }^{165}$ Within the proposed framework of government speech, such deterrence clearly constitutes a restraint on individual expression.

\section{B. The Positive Effects of the Label}

The government is umiquely capable of, and responsible for, protect-

158. See supra note 49 and accompanying text.

159. The Court in Keene stated that "it is our duty to construe legislation as it is written, not as it might be read by a layman, or as it might be understood by someone who has never read it." 481 U.S. 465, 484-85 (1987). The Court's earlier precedent suggested deferring to the congressional definition was appropriate. The Court noted that it was "axiomatic that the statutory definition of the term excludes unstated meanings of that term." Id. at 484 (citing Colautti v. Franklin, 439 U.S. $379,392 \&$ n.10 (1979)). Generally, the standard language of the statute will control unless there is a "clearly expressed legislative intention to the contrary." Consumer Prod. Safety Comm'n v. GTE Sylvania, 447 U.S. 102, 108 (1980); see, e.g., Perrin v. United States, 444 U.S. 37 (1979) (legislative history indicates Congress made no effort to define the term "bribery" but relied on contemporary meaning), cert. denied sub nom. La Font v. United States, 444 U.S. 980 (1979) and cert. denied sub nom. Levy v. United States, 444 U.S. 990 (1979).

160. Compare L. Carroll, Through the looking-Glass, and What Alice Found THERE 66 (University of Cal. ed. 1983) (" 'When I use a word,' Humpty Dumpty said in a rather scornful tone, 'it means just what I choose it to mean-neither more nor less.' "), quoted in Keene v. Smith, 569 F. Supp. 1513, 1522 (E.D. Cal. 1983), rev'd sub nom. Meese v. Keene, 481 U.S. 465 (1987) with Carter, Constitutional Adjudication and the Indeterminate Text: A Preliminary Defense of an Imperfect Muddle, 94 YALE L.J. 821, 823 (1985) ("A text's only meaning is the one given by the interpreter, who in turn aiways reads a text against a particular social and political backdrop.") (discussing deconstructionism).

161. See supra notes $119-25$ and accompanying text.

162. See supra notes $38-39$ and accompanying text.

163. See supra note 142 and accompanying text.

164. See supra notes $150-56$ and accompanying text.

165. See supra notes $105-06$ and accompanying text. 
ing the national security and managing relations with other nations. ${ }^{166}$ Therefore, the public benefits significantly from government speech that provides information not otherwise available to the public but necessary for the maintenance of national security. Consequently, the propaganda label could serve important societal interests by informing the public of possible sources of bias in the films relating to national security. Whatever benefits the label creates, lowever, are negated by the terminology that the label uses: "propaganda" not only points out the possibility of bias in the films, but it also passes judgment on that possibility. The labehing requireinent can be used to promote the government's interest in providing objective information to the public, without usurping the public's role in evaluating the information, by either replacing the FARA label with a term that is not so loaded with a political message, ${ }^{167}$ or sinply disclosing the country of origin and the name of the distributor. Such labels would serve some important informational interests, but would still leave judgments regarding political choice to the public.

\section{The Negative Effects of the Label}

Part II of this Note outlimed three areas of society that could be adversely affected by government speech. ${ }^{168}$ The facts of Keene indicate that the official label on fillns would liave had a negative impact on each of those areas.

1. The Majority. The public's natural tendency to rely on the accuracy of government speech ${ }^{169}$ makes the FARA label a powerful and persuasive statement. As the statute now operates, the label gives the public information that may crowd out other information and lead to decisions based not on the merits of the filins but on the authority of the governinent. ${ }^{170}$ In this way, the government could affect indirectly the showing of the films, soinething it probably could not accoinplish directly. Another risk is that the governinent could use the labeling provision by designating all fillns produced in certain types of countries as propaganda. ${ }^{171}$ This certainly would add force to the majority's position and enable the governinent to shape the public debate.

166. See supra note 111 and accompanying text.

167. For example, the language could be changed to "political advocacy" or "political information." See Note, Political Propoganda Label, supra note 10, at 623 \& n. 184.

168. See supra notes $118-56$ and accompanying text.

169. See supra notes $119-21$ and accompanying text.

170. See supra notes 122-25 and accompanying text.

171. See supra note 125 and accompanying text. 
2. The Minority Elements. The situation in Keene demonstrates how government speech can inhibit the expression of dissenting opinions. Keene alleged that he disliked having to risk being seen as a "propagandist," and that he should not have to bear that badge just to speak. ${ }^{172}$ His fears seem reasonable-one need not be "timid"173 to want to avoid the label of propagandist.

3. Information in the Ideological Marketplace. As discussed earher, ${ }^{174}$ all properly functioning markets require informed participants. The public, however, probably would not know one important aspect of the labeling provision - the fact that a very few, relatively low-level, civil servants determme whether to label a particular film as propaganda. Because the number of bureaucrats who reviewed the film was small, and because the bureaucrats' decision was made outside of the arena of political accountability, personal pohtical bias easily could have been a major factor in the decision. Without this information, moreover, the public could not intelligently evaluate the FARA label or the content of the films, thereby giving the government speech undue weight in the ideological marketplace.

\section{Balancing the Interests}

The proposed constitutional framework for government speech would require the court to balance the various interests implicated by government expression. On the one hand, the government's interest in Keene in providing information to help maintain national security was valid. On the other hand, the public possessed an equally valid interest in preventing the government from coercing consent from the majority, inhibiting minority expression, and competing unfairly in the ideological marketplace. The public's interest almost certainly outweighed that of the government. Thus, although a court, relying on traditional first amendment analysis, would rule for the government, a court using the proposed first amendment framework could decide in favor of Keene. Although the results in cases like Keene might be strikingly different, the two frameworks for analysis differ principally in the extent to which they take a sophisticated approach to the complexities of the communication process.

172. See supra note $50-52$ and accompanying text.

173. See supra note 142 and accompanying text.

174. See supra note 150 and accompanying text. 


\section{CONClusion}

Of course, the Supreme Court may not have ruled differently in Keene even if it had used the framework proposed in this Note. The foregoing discussion has shown, however, that a different result at least would have been possible. And if Keene would not have been resolved differently, the proposed framework certainly would have an effect in other cases.

If nothing else, Keene illustrates the need for courts to develop first amendment analysis to account for government speech - a constitutional theory that recognizes and takes account of the power and influence of the government in its role as speaker. Such analysis must be sensitive to the many indirect ways in which the government may attempt to restram individual expression. Moreover, this frainework should evaluate the positive and negative effects of government speech on the public's ability to govern itself effectively. This franework does not differ radically from traditional first amendment analysis: whether exphicitly or implicitly, courts always have used a balancing test to determine if a restraint on individual expression violates first amendment protections. The proposed framework simply recognizes that the nature of the speaker is a significant aspect in first ainendment doctrine, and the government, as speaker, inherently threatens individual autonoiny and self-governance.

Brian C. Castello 